\title{
Effect of Artificial Recharge Structures in Improving Groundwater Level
}

\author{
G. Thiyagarajan ${ }^{1}$, A. Valliammai ${ }^{2}$, A. Raviraj $^{1}$ and S. Panneerselvam ${ }^{1}$ \\ ${ }^{1}$ Water Technology Centre, Tamil Nadu Agricultural University, Coimbatore, India \\ ${ }^{2}$ Agricultural Research Station, Tamil Nadu Agricultural University, Bhavanisagar, India \\ *Corresponding author
}

\section{A B S T R A C T}

\section{Keywords}

Artificial recharge; Check dam;

Groundwater level; Recharge shaft; Recharge borewell

\section{Article Info}

Accepted:

08 January 2020

Available Online:

10 February 2020
Artificial recharge is a technique used to replenish the groundwater resources which exploited by pumping for irrigation and drinking purpose. An artificial recharge structures are practiced in the hard rock regions of Tamil Nadu for groundwater restoration and management. The effectiveness of recharge structures in improving the recharge process has been evaluated for different recharge structures, namely, check dams, recharge shaft in percolation pond and recharge borewell. The recharge during the northeast monsoon for a period upto December is about 11.4 per cent and during the southwest monsoon for a period upto September is about 15.6 per cent. Natural recharge, depth of increase in groundwater is $1.5 \mathrm{~m}$ whereas the areas having artificial recharge structures the increase in groundwater table is $4.7 \mathrm{~m}$. The recharge rate of a check dam and recharge shaft in percolation pond were estimated as $0.27 \mathrm{~m}^{3} / \mathrm{m}^{2}$ of ponding area/month and 0.54 $\mathrm{m}^{3} / \mathrm{m}^{2}$ of ponding area/month respectively. The recharge shaft in percolation pond was found to be more effective in recharging the groundwater.

\section{Introduction}

India is an agrarian country where about $85 \%$ of the population depends on groundwater for irrigation and domestic needs. Extraction of groundwater for irrigation where it is slowly renewed is the main cause for depletion (Hertig and Gleeson, 2012). Agricultural activities mostly depend on the use of groundwater especially in southern part of India. Groundwater depletion and its impact is more obvious at the regional scale in agriculturally important parts of India. Artificial recharge is a technique used to prevent over exploitation of groundwater resources.

Artificial recharge is the progression of replenishing groundwater by augmenting the natural infiltration of rainwater or surface water into sub surface aquifers through several methods depending on the slope 
Geomorphology, geology and soil conditions. Artificial recharge structures are practiced in the hard rock regions of Tamil Nadu for groundwater restoration and management.

The previous studies showed that the most commonly used method for natural recharge estimation is the mass balance approach (Rushton et al., 2006; Sophocleous, 1991; Stone et al., 2001). The influence of percolation pond in artificial recharge of a semi-arid region of India was observed that 30-35 percent of the impounded water was recharged through the pond (Sukhija et al., 1997). The response of two percolation ponds in TamilNadu, India was studied to assess their potential influence zones. They observed that the strongly influenced wells were located within $400 \mathrm{~m}$ from the ponds whereas moderately influenced wells were located up to $800 \mathrm{~m}$ from the ponds (Jothiprakash et al., 2002). In the present study, the existing artificial recharge structures in Thondamuthur block of Noyyal sub basin was selected to assess the impact of artificial recharge structures in improving the groundwater level.

\section{Materials and Methods}

\section{Study area}

The location map of Thondamuthur block is shown in Figure 1. It falls within the coordinates of longitude $76^{\circ} 40^{\prime} 00^{\prime \prime}$ to $77^{\circ} 02^{\prime} 00^{\prime \prime} \mathrm{E}$ and latitude $10^{0} 56^{\prime} 00^{\prime \prime}$ to $11^{0} 03^{\prime} 00^{\prime \prime} \mathrm{N}$ of Survey of India toposheet numbers $56 \mathrm{~B} / 13,58 \mathrm{~B} / 16$ and $58 \mathrm{~F} / 1$. It has a geographical area of $480 \mathrm{Km}^{2}$. Six recharge structures were identified in the study area. Four check dams, one recharge shaft in check dam and one recharge bore well was identified for the study. The ten observation wells near the structures were also identified for monitoring the water levels. The location of the recharge structures and observation wells were tabulated in Table 1 and Table 2 respectively. The specifications of the recharge structures were given in the Table 3 (a) to (c).

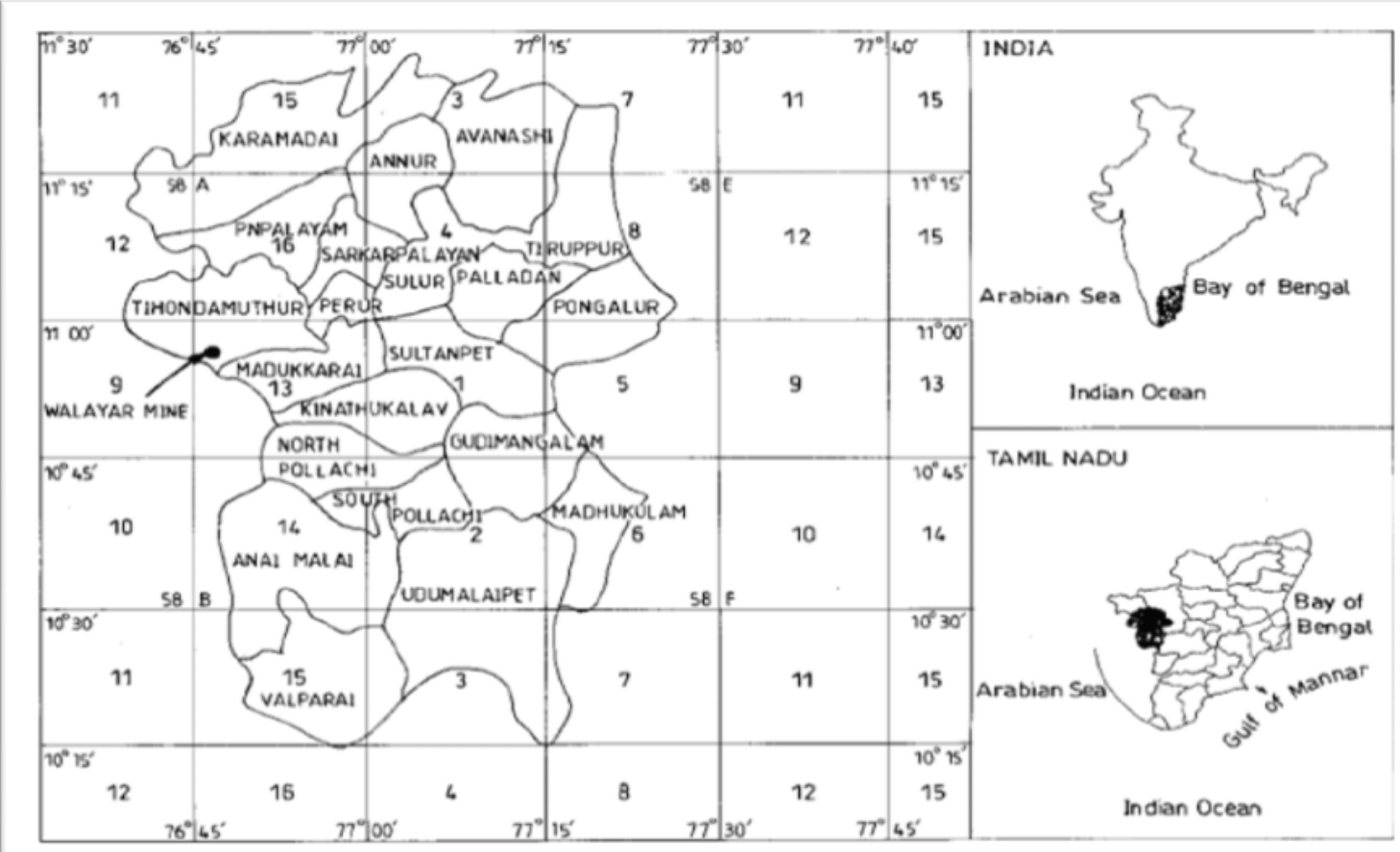

Fig.1 Location map of Thondamuthur block 
Table.1 Location of recharge structures

\begin{tabular}{|c|l|c|c|}
\hline Sl. No. & \multicolumn{1}{|c|}{ Recharge structure } & Latitude & Longitude \\
\hline 1. & Recharge bore well in check dam & $11^{\circ} 00^{\prime} 25^{\prime \prime} \mathrm{N}$ & $76^{\circ} 49^{\prime} 53^{\prime \prime} \mathrm{E}$ \\
\hline 2. & Recharge bore well & $11^{\circ} 00^{\prime} 11^{\prime \prime} \mathrm{N}$ & $76^{\circ} 48^{\prime} 15^{\prime \prime} \mathrm{E}$ \\
\hline 3. & Check dam 1 & $10^{\circ} 56^{\prime} 22^{\prime \prime} \mathrm{N}$ & $76^{\circ} 45^{\prime} 03^{\prime \prime} \mathrm{E}$ \\
\hline $\mathbf{4 .}$ & Check dam 2 & $10^{\circ} 57^{\prime} 22^{\prime \prime} \mathrm{N}$ & $76^{\circ} 46^{\prime} 03^{\prime \prime} \mathrm{E}$ \\
\hline $\mathbf{5 .}$ & Check dam 3 & $10^{\circ} 59^{\prime} 51^{\prime \prime} \mathrm{N}$ & $76^{\circ} 04^{\prime} 48^{\prime \prime} \mathrm{E}$ \\
\hline $\mathbf{6 .}$ & Check dam 4 & $10^{\circ} 58^{\prime} 16^{\prime \prime} \mathrm{N}$ & $76^{\circ} 48^{\prime} 01^{\prime \prime} \mathrm{E}$ \\
\hline
\end{tabular}

Table.2 Location of observation wells

\begin{tabular}{|c|l|c|c|}
\hline Sl. No. & Observation Wells & Latitude & Longitude \\
\hline $\mathbf{1 .}$ & Well No. 1 & $10^{\circ} 58^{\prime} 54^{\prime \prime} \mathrm{N}$ & $76^{\circ} 48^{\prime} 19^{\prime \prime} \mathrm{E}$ \\
\hline $\mathbf{2 .}$ & Well No. 2 & $10^{\circ} 58^{\prime} 47^{\prime \prime} \mathrm{N}$ & $76^{\circ} 50^{\prime} 25^{\prime \prime} \mathrm{E}$ \\
\hline $\mathbf{3 .}$ & Well No. 3 & $10^{\circ} 59^{\prime} 06^{\prime \prime} \mathrm{N}$ & $76^{\circ} 48^{\prime} 58^{\prime \prime} \mathrm{E}$ \\
\hline $\mathbf{4 .}$ & Well No. 4 & $10^{\circ} 59^{\prime} 20^{\prime \prime} \mathrm{N}$ & $76^{\circ} 49^{\prime} 01^{\prime \prime} \mathrm{E}$ \\
\hline $\mathbf{5 .}$ & Well No. 5 & $10^{\circ} 59^{\prime} 38^{\prime \prime} \mathrm{N}$ & $76^{\circ} 49^{\prime} 05^{\prime \prime} \mathrm{E}$ \\
\hline $\mathbf{6 .}$ & Well No. 6 & $10^{\circ} 59^{\prime} 25^{\prime \prime} \mathrm{N}$ & $76^{\circ} 48^{\prime} 28^{\prime \prime} \mathrm{E}$ \\
\hline $\mathbf{7 .}$ & Well No. 7 & $10^{\circ} 58^{\prime} 05^{\prime \prime} \mathrm{N}$ & $76^{\circ} 48^{\prime} 22^{\prime \prime} \mathrm{E}$ \\
\hline $\mathbf{8 .}$ & Well No. 8 & $10^{\circ} 58^{\prime} 16^{\prime \prime} \mathrm{N}$ & $76^{\circ} 48^{\prime} 40^{\prime \prime} \mathrm{E}$ \\
\hline $\mathbf{9 .}$ & Well No. 9 & $10^{\circ} 59^{\prime} 32^{\prime \prime} \mathrm{N}$ & $76^{\circ} 50^{\prime} 30^{\prime \prime} \mathrm{E}$ \\
\hline $\mathbf{1 0 .}$ & Well No. 10 & $10^{\circ} 59^{\prime} 09^{\prime \prime} \mathrm{N}$ & $76^{\circ} 50^{\prime} 25^{\prime \prime} \mathrm{E}$ \\
\hline
\end{tabular}

To estimate the water balance between evaporation and recharge losses from the percolation pond/check dam, the change in pond water level with time was monitored. For periods without direct abstraction and rainfall, this is translated into groundwater recharge rates after subtracting open pan evaporation rates.

The water balance for a reservoir can be simplified if losses due to leakage, abstraction etc. can also be neglected and if the pond is under effluent conditions in relation to the aquifer, then the water balance can be written as follows (Aish and Smedt, 2006).

Groundwater Recharge $=$ Change of volume of water in the pond-Evaporation
Under such conditions, the balance between evaporation and groundwater recharge will determine the effectiveness of the artificial recharge.

\section{Groundwater recharge}

Groundwater recharge estimation is done by the water level fluctuation method. The observation of water levels in the observation wells were done. The specific yield of the aquifer formation in the study area is found to vary between 0.9 to 1 per cent and influencing area is taken as $1.0 \mathrm{sq} \mathrm{km}$. The recharge volume is given by,

Recharge volume, $\mathrm{R}\left(\mathrm{m}^{3}\right)=$ Area $\left(\mathrm{m}^{2}\right) \times$ Average water level fluctuation $(\mathrm{m}) \times$ Specific yield. 
Table 3.Specification of the recharge structures

a. Check dams

\begin{tabular}{|c|c|c|c|}
\hline $\begin{array}{c}\text { Structure } \\
\text { name }\end{array}$ & $\begin{array}{c}\text { Max storage area } \\
\text { (ha) }\end{array}$ & $\begin{array}{c}\text { Max storage } \\
\text { depth(m) }\end{array}$ & $\begin{array}{c}\text { Catchment } \\
\text { area(Sq.km) }\end{array}$ \\
\hline CD1 & 0.17 & 1.3 & 1.10 \\
\hline CD2 & 0.20 & 1.5 & 1.36 \\
\hline CD3 & 0.22 & 1.5 & 1.40 \\
\hline CD4 & 0.26 & 1.5 & 1.38 \\
\hline
\end{tabular}

\section{b. Recharge shaft}

\begin{tabular}{|l|l|}
\hline Bore size and depth & $\mathbf{6 . 5 "} \Phi$ to depth of $\mathbf{1 0 0 m}$ \\
\hline $\begin{array}{l}\text { Filtering chamber surround the } \\
\text { shaft }\end{array}$ & $\begin{array}{l}\text { Circular pit of } 5 \mathrm{~m} \Phi \text { and } 4.5 \mathrm{~m} \text { depth } \\
\text { around the shaft filled with filtering media }\end{array}$ \\
\hline Slotted PVC casing pipe & $\Phi=6.5^{\prime \prime}$, length $=12 \mathrm{~m}$ \\
\hline
\end{tabular}

c. Recharge bore well

\begin{tabular}{|l|l|}
\hline Bore size and depth & $\mathbf{6 . 5}$ "Фto depth of $\mathbf{1 0 0 m}$ \\
\hline Filtering pit & $\begin{array}{l}\text { Square }-3 \times 3 \times 1.5 \mathrm{~m} \text { filled with filtering } \\
\text { media }\end{array}$ \\
\hline Slotted PVC casing pipe & $\Phi=6.5^{\prime \prime}$, length $=6$ to $12 \mathrm{~m}$ \\
\hline
\end{tabular}

\section{Results and Discussion}

The effectiveness of different artificial recharge structures, namely check dam, recharge shaft and recharge borewells were evaluated through experimental studies. Water level data was collected from wells within the influence zone and the fluctuations were analyzed before and after artificially recharging the aquifer.

Water level fluctuations and water balance approaches were used to quantify the individual and combined effectiveness of various artificial recharge structures in recharging the groundwater aquifer.

The water levels increased slightly around 1.5 $\mathrm{m}$ during July due to south west monsoon and it reduced during September month. Due to rainfall in north east monsoon and stored water in check dams and recharging through recharge borewells, the water level was again increased in all the observation wells during December (4.7 m BGL). The recharge during the northeast monsoon for a period upto December is about 11.4 per cent with average water level fluctuation of about $0.5 \mathrm{~m}$ in the study area. The recharge during the southwest monsoon for a period upto September is about 
15.6 per cent with average water level fluctuation of about $0.61 \mathrm{~m}$ in the study area. Natural recharge, depth of increase in groundwater is $1.5 \mathrm{~m}$ whereas the areas having artificial recharge structures the increase in groundwater table is $4.7 \mathrm{~m}$.

The maximum water level improvement was observed near the recharge structures at downstream side. The recharge rate of a check dam and recharge shaft in percolation pond were estimated as $0.27 \mathrm{~m}^{3} / \mathrm{m}^{2}$ of ponding area/month and $0.54 \mathrm{~m}^{3} / \mathrm{m}^{2}$ of ponding area/month respectively.

Mass balance approach showed that on an average 80-90 percent of the change in volume in the case of ponding structures was contributing to the recharging of the aquifer rather than being lost to evaporation.

It was also observed that there was considerable variation of water level with time and location. Similar results were also reported by Raviraj et al., 2007, Saxena et al., 2010 and Marykutty Abraham and Mohan, 2015.

The effectiveness of different artificial recharge structures, namely check dam, recharge shaft in percolation pond and recharge bore well were evaluated and reported in this paper.

Water level were collected from wells within the influence zone and the fluctuations were analysed before and after artificially recharging the aquifer. Water level fluctuations and water balance approaches were used to quantify the effectiveness of various artificial recharge structures in recharging the groundwater aquifer.

From the results of the study, it can be concluded that among the different artificial recharge structures studied, the recharge shaft in percolation pond was found to be more effective in recharging the groundwater. From the study it was found that artificial recharge is a viable solution for sustainable development of groundwater resources.

\section{References}

Aish, A. andSmedt, F. 2006.Modeling of a groundwater mound resulting from artificial recharge in the Gaza Strip, Palestine. Water for Life in the Middle East, 2:779-787.

Hertig, A.W., T. Gleeson. 2012. Regional strategies for the accelerating global problem of groundwater depletion. Nature Geoscience, 5:853-861.

Jothiprakash, V., Mohan, S. and Elango, K. 2002.Artificial recharge through percolation ponds.In: International Conference on Sustainable Development and Management of Groundwater Resources in Semi-Arid Regions with Special Reference to Hard Rock. New Delhi: Oxford and IBH Publishing Co. Pvt. Ltd.; 194-197.

Marykutty Abraham and Mohan, S. 2015. Effectiveness of Artificial Recharge Structures in enhancing Groundwater Storage: A Case Study. Indian Journal of Science and Technology, 8(20): 1-10.

Raviraj, A., Ranghaswami, M.V., Mayilswami, C. and Palanisami, K. 2007. Groundwater recharge in a hard rockregion of Coimbatore district, Tamil Nadu - A case study. Proceedings of International Groundwater Conference held at TNAU.

Rushton, K.R., Eilers, V.H.M. and Carter, R.C. 2006.Improved soil moisture balance methodology for recharge estimation. Journal of Hydrology, 318 (1-4): 379-399.

Saxena, P., Chandra, A., Garg, A., Sharma, G. and Varma, P. 2010. Conservation of groundwater by artificialrecharge in 
Delhi and Haryana State of India-A review. Int. J. App. Bio. Pharmaceutical Tech., 1 (3), 989-993.

Sophocleous, M.A. 1991. Combining the soilwater balance and water-level fluctuation methods to estimate natural ground-water recharge-practical aspects. Journal of Hydrology, 124 (34): 229-241.

Stone, D.B., Moomaw, C.L. and Davis, A. 2001.Estimating recharge incorporating runoff from mountainous areas in an alluvial basin in the Great Basin regions of the South Eastern United States. Ground Water, 39 (6): 807-818.

Sukhija, B.S., Reddy, D.V., Nandakumar, M.V. and Rama. 1997. A method for evaluation of artificial recharge through percolation tanks using environmental chloride. Groundwater, 35 (1): 161165.

\section{How to cite this article:}

Thiyagarajan. G, A. Valliammai, A. Raviraj and Panneerselvam. S. 2020. Effect of Artificial Recharge Structures in Improving Groundwater Level. Int.J.Curr.Microbiol.App.Sci. 9(02): 923-928. doi: https://doi.org/10.20546/ijcmas.2020.902.109 